J. Product. \& Dev., 26(1):119-137 (2021)

\title{
PERFORMANCE OF SWEET SORGHUM (Sorghum bicolor L.) GERMPLASM RESOURCES FOR THEIR INDUSTRIAL TRAITS UNDER EGYPTIAN CONDITIONS
}

\author{
Yehia A. Khidr; Sileshi A. Mekuriaw; Enass Amer and Adel E. Hegazy \\ ${ }^{1}$ Department of Plant Biotechnology, Genetic Engineering and \\ Biotechnology Research Institute, University of Sadat City, Egypt. \\ *Corresponding author: yehia.khidr@gerbi.usc.edu.eg
}

\section{ABSTRACT}

Sweet sorghum is an emerging versatile crop species that offers grain for human consumption, fodder for livestock and ethanol for transportation purposes. The knowledge on industrial characters including juice quality traits and sugar components is an indispensable task for improving the crop at commercial level and establish sustainable value chain. In the current study a set of 68 sweet sorghum genotypes comprising land race collections and improved cultivars were evaluated for their fresh biomass yield, stripped stalk yield, dry matter yield, juice yield and quality traits (Purity\%, Glucose Recovery\%, Reducing sugar\%, Sucrose\%, and Total soluble sugar). The genotypes showed significant level of variation at $p \leq 0.01$ for all the eleven industrial traits regarding the five juice quality parameters measured. The juice purity of the genotypes ranged between $46.04 \%$ and $100 \%$. The total soluble solids of the test genotypes had displayed a maximum value of 24.5 and a minimum of 10 . The sucrose percent (pol) was found to range between $7.2 \%$ and $17.76 \%$ percent. This indicates the presence of promising possibility for the future improvement of the crop. The test genotypes were found to be clustered into five distinct clusters. Conclusively, the tested sweet sorghum genotypes displayed a broad range of variability in terms of all the measured industrial crops. The juice quality parameters in the test genotypes were found to be significantly higher as compared to different commercial improved cultivars. This indicates the presence of promising possibility for the future improvement of the crop. The test genotypes were found to be clustered into five distinct clusters. In conclusion, the present study demonstrates that the evaluated sweet 
sorghum genotypes had superior performance in terms of their juice yield and quality traits.

Hence, they could be exploited in the future improvement of the crop as an industrial crop.

Keywords: Brix, TSS, Purity, Sucrose

\section{INTRODUCTION}

Sorghum (Sorghum bicolor L. Moench) is among the top globally important cereals standing $6^{\text {th }}$ in terms of its production (63.9 million MT) and $5^{\text {th }}$ in area harvested (58 million hectares) (FAO, 2019) (http://faostat3.fao.org/browse/Q/QC/E). Due to its versatility and unique ability of abiotic stress tolerance it remains to be a staple food crop in the semi-arid tropics of Africa and India where low-input subsistence farming is the main stay. On the other hand, countries like the USA, Mexico, Argentina, Australia and China produce sorghum on a commercial basis, principally for feed, export and recently also biofuel (ethanol). Although sorghum is principally cultivated on marginal sites which are too dry for other crops such as maize and wheat, grain yields of $20 \mathrm{t} \mathrm{ha}^{-1}$ and dry matter yield of $80 \mathrm{t} \mathrm{ha}^{-1}$ (Packer \& Rooney, 2014) have been reported in the US under optimal conditions.

In Egypt, sorghum holds fourth place in use and production after wheat, maize and rice mostly concentrated in Assiut and Sohag governorates where the atmospheric temperature is high (Al-Naggar et al., 2007). In 2017 the area of cultivation for grain sorghum in Egypt was estimated about 148,460 hectares with annual production of 804,000 tons (FAOSTAT, 2017) and average yield of $5.42 \mathrm{t} / \mathrm{ha}$ (Khaled et al., 2019).

Currently, there is a growing interest to cultivate sweet sorghum for the production of sugar or ethanol in tropical and subtropical areas which are too dry or where winters are too cold for sugarcane (Burks et al., 2015, Mocoeur et al., 2015, Regassa \& Wortmann 2014). The sorghum crop could also be potentially exploited as a multipurpose crop to produce multitudes of products under dessert ecologies with minimal water requirement.

Sweet sorghum has also a potential of producing comparable or even higher sugar and biomass yield to sugarcane in a short growth cycle (120-130 days), while displaying unique stress tolerance capacity (Almodares and Hadi, 2009; Rooney et al. 2007; Wu et al., 2010) and wider adaptability which makes sweet sorghum remains to be an ideal bioenergy crop of exceptional qualities. In 
addition to higher biomass yield, the sweet sorghum accumulates higher levels of non-structural soluble sugars mostly sucrose in the stem which renders the crop to be an ideal bioenergy crop and a good genetic model for related species like sugarcane (Wang et al., 2013). Moreover, it is a well-established fact that sweet sorghum is a carbon neutral crop as the amount of carbon dioxide that sweet sorghum fixes is equal to the amount that it emits during the entire process of crop growth and processing.

Evaluation and characterization of germplasm are the pre-requisite for the utilization of the available diversity in the crop improvement program. Despite its growing importance, sweet sorghum has been receiving relatively little attention in terms of improving sweet sorghum sugar yields, suggesting that rapid genetic improvement is the way forward (Burks et al., 2013). Hence, sweet sorghum improvement should be geared towards increasing sugar and juice yield and quality. This calls for extensive characterization of sweet sorghum germplasm resources for their industrial traits including sugar and juice quality analysis.

Several studies revealed that the existence of significant natural genetic variability in sweet sorghum in different industrial traits such as juice yield, sugar content (Brix), and biomass yield (Almodares \& Sepahi, 1996; Makanda, Tongoona, \& Derera, 2009). This signifies the fact that there is a significant potential in the improvement of the crop for industrial and commercial level of cultivation.

Hence, this study is designed to analyze sugar and juice quality traits of sweet sorghum genotypes of different origins. And quantify the performance of sweet sorghum germplasm materials for industrial traits like stem fresh weight, stripped cane weight, dry matter yield, brix, and juice yield.

\section{MATERIALS AND METHODS}

\section{Field Experiment \\ Study Site}

A field experiment was conducted at the Agricultural Research Farm of the University of Sadat city located at $30.60^{\circ} \mathrm{N}$ and $30.22^{\circ} \mathrm{E}$. The experiment was conducted in two consecutive summer cropping seasons (2018 and 2019) starting from early June to October each year. The area is characterized by semi-arid to arid climatic conditions (desert condition) with long and hot 
summer season and warmer winter with very low precipitation of about 10 $\mathrm{mm} /$ year. The soil generally of dry siliceous coarse sand.

\section{Plant material}

Sixty-eight sweet sorghum genotypes comprising 49 landraces (accessions) and 5 cultivars from Ethiopia, and 14 cultivars obtained from the sugar crops research institute (ARC) in Egypt (Table 1) were used. The term landrace refers to variable populations adapted to local agro- climatic conditions which are named, selected and maintained by the traditional farmers to meet their social, economic, cultural and ecological need while accessions are samples collected from the landraces from farmers' fields for research purposes (Teshome et al., 1997).

\section{Experimental design and crop husbandry}

The experiments were laid out using randomized complete block design with three replications in both years. Dimensions of the plots were three rows each $8 \mathrm{~m}$ long and the seeds were drilled with $0.75 \mathrm{~m}$ spacing between rows. Crop husbandry practices were done according to the recommended guidelines of the agricultural research center. Nitrogen fertilizer was added at the rate of $238 \mathrm{~kg} / \mathrm{ha}$ as Urea $(46.5 \% \mathrm{~N})$ in split application comprising two equal doses. The first dose during the first irrigation and the second after 35 days of emergence. Superphosphate fertilizer (15\% P2O5) was added at the rate of $70 \mathrm{~kg}$ P2O5/ha as soil application before sowing during planting. Potassium fertilizer at the rate of $57 \mathrm{~kg} \mathrm{~K} 2 \mathrm{O} / \mathrm{ha}$ was also applied during planting in a form of potash (48\% $\mathrm{K} 2 \mathrm{O}$ ). Other cultural practices were carried out following the recommendations of ARC. The plots were irrigated at two weeks interval using drip irrigation and kept weed free during the growing period. All the standard crop husbandry practices were done according to the recommended guidelines.

\section{Data collection}

Data were recorded on the following industrial traits related to juice and biomass yield and quality traits. Fresh Biomass yield (FBY) was recorded by weighing five plants randomly selected from the central row cut at the base and the mean was taken. Stripped stalk weight (SSW) was recorded after removing the leaf and panicles of the sampled plants. Dry Stover yield (DSY): the five plants (without panicles) were chopped, mixed 
and a handful of sub-samples were weighed and saved in a paper bag were dried for 3 days at $60^{\circ} \mathrm{C}$. The dry Stover yield was calculated by dividing the dried Stover weight by fresh Stover weight multiplied by fresh biomass yield. Juice was extracted from the selected plats to measure the juice yield and quality parameters during the hard dough stage. The tagged plants were cut at the middle internodes and pressed using a garlic press to measure the brix degree using a handheld digital refractometer (Digital hand-held pocket refractometer PAL-1, Atago, Tokyo, Japan). Other juice quality traits were analyzed using saccharimeter for determination of sucrose and Redutec $\AA$ for determination of reducing sugars. The juice quality variables were computed as detailed below using formulas adapted from Paulo- Consecana (2006).

Juice yield (JY) was taken after the juice was extracted from the remaining three plants by a three-roller motorized digester and weighed. Juice extraction rate $(\%)$ : was computed by dividing weight of fresh juice by fresh stalks weight of the three plants and multiplying by 100. Juice yield $\left(\mathrm{Mg} \mathrm{ha}^{-1}\right)$ was computed by multiplying juice weight from 10 plants by plants per hectare. Brix was measured using handheld digital refractometer. The refractometer was calibrated according to the manufacturers manual and thoroughly rinsed using distilled water and dried with tissue paper between consecutive measurements. Brix is a measure of dissolved sugar to water mass ratio of a liquid where one-degree Brix is equivalent to $1 \mathrm{~g}$ of soluble sugars in $100 \mathrm{~g}$ of solution. The recorded brix values were corrected by using the Schmitz's table as described in A.O.A.C (2005).

\section{Laboratory analysis}

The juice quality analysis was performed at the Sugar Crops Research Institute, Agricultural Research Center, Giza, Egypt.

Sucrose content (Pol percent): corresponds to sucrose concentration in the juice (POL, in \%), which is the measure of the amount of sucrose in the sugar mixture. This was directly measured using NIR Saccharimeter 880D (Optical Activity Limited, Cambridge shire, UK) without using lead acetate clarification was calculated from $100 \mathrm{~cm}^{3}$ of juice. Sucrose content was calculated as follows:

Sucrose percentage $=$ Direct reading of Saccharimeter $\times 1.04$; Where, 1.04 is a factor depending on the length of Saccharimeter's tube (A.O.A.C. 2005).

Juice Purity (Purity): was calculated using the following equation: as = (sucrose percentage / Brix reading) x 100 . 
Theoretical sugar recovery (SR): was calculated according to the formula described by Legendre and Henderson (1972): Sugar recovery percentage = $[\mathrm{S}-0.4(\mathrm{~B}-\mathrm{S})] \times 0.73$; Where: $\mathrm{B}=$ Brix percentage, $\mathrm{S}=$ sucrose percentage, 0.4 and 0.73 constant factors.

The total soluble sugars (TSS): were determined using automatic digital refractometer as juice brix measured from pooled juice extracted from sample plants.

The theoretical ethanol yield was estimated following the procedures of (Wortmann, 2010) assuming 75\% of the brix as fermentable sugars and $80 \%$ juice extraction efficiency.

$$
\begin{gathered}
C S Y=(S C Y-D S Y) \times \frac{\text { Brix }}{100} \times 0.75 \mathrm{ly}=[S C Y-(D S Y-C S Y)] \times 0.8 \\
S Y=J Y \times \frac{\text { Brix }}{100} \times 0.75 \\
T E T O H Y=S Y(\mathrm{~kg} / \mathrm{ha}) \times 0.585
\end{gathered}
$$

Where: CSY is conservative sugar yield $\left(\mathrm{kg} \mathrm{ha}^{-1}\right)$, SCY is stripped cane yield $(\mathrm{kg} \mathrm{ha}-1)$, DSY is dry stalk yield $\left(\mathrm{kg} \mathrm{ha}^{-1}\right), \mathrm{JY}$ is juice yield $\left(\mathrm{kg} \mathrm{ha}^{-1}\right)$ assuming $80 \%$ extraction rate, and SY is sugar yield $\left(\mathrm{kg} \mathrm{ha}^{-1}\right)$ assuming $75 \%$ of the brix to represent fermentable sugar. TETOHY is the theoretical ethanol yield and 0.585 is the correction factor (liter per kilogram of sugar) derived from the theoretical maximum yield of ethanol after complete fermentation of sucrose and native glucose equivalent to $3.8 \mathrm{~L}$ of ethanol for every $6.7 \mathrm{~kg}$ of sugar (Lueschen et al., 1991).

\section{Analysis of variance (ANOVA)}

The data collected for each character was subjected to analysis of variance (ANOVA) using procglimms in SAS (2014) to test the variations among genotypes for agro-morphological traits. One-way ANOVA for the juice quality traits was conducted using the ANOVA function in Microsoft Excel at the 0.05 significance level. Mean separation was conducted with Duncan multiple range testing (DMRT) at 5\% probability levels using SAS (2014).

\section{Estimates of variance components:}

The total variability present in the population which is attributed to of genotype $\left(\delta_{G}^{2}\right)$, environment in our case variance over years $\left(\delta_{\mathbb{R}}^{2}\right)$ and their interaction $\left(\delta_{\mathrm{GRE}}^{2}\right)$ together with coefficient of variation for each character as percentage of means were estimated. The variance components were 
estimated using COVTEST in SAS (Version 14.1). The phenotypic variance among genotypes grown in $\mathrm{r}$ replications and $\mathrm{n}$ environments (years) was computed based on formula Syukur et al. (2012) using the above values as:

$$
\delta_{\mathrm{p}}^{2}=\left[\delta_{\mathrm{G}}^{2}+\left(\frac{\delta_{\mathrm{GXE}}^{2}}{\mathrm{n}}\right)+\left(\frac{\delta_{\mathrm{E}}^{2}}{\mathrm{nr}}\right)\right.
$$

Where, $\delta_{\mathrm{G}}^{2}=$ Genotypic variance, $\delta_{\mathrm{GxE}}^{2}=$ variance due to the interaction between genotype $\mathrm{x}$ environment; $\delta_{\mathrm{E}}^{2}=$ experimental error variance.

The genotypic coefficient of variation GCV $=\frac{\sqrt{\delta_{\mathrm{G}}^{\mathrm{g}}}}{\mathrm{x}}$; phenotypic coefficient of variation PCV $=\frac{\sqrt{\delta_{\mathrm{P}}^{2}}}{\mathrm{X}}$ where: $\mathrm{X}$ is grand mean of a character.

\section{Estimation of heritability and genetic advance}

Broad sense heritability $\left(\mathrm{h}^{2}\right)$ of all the traits was calculated according to the formula as described by Allard (1960) as follows:

$$
\mathrm{h}^{2}=\frac{\delta_{\mathrm{G}}^{\frac{\pi}{2}}}{\delta \frac{\pi}{\mathrm{P}}} \times 100
$$

Where: $h^{2}=$ Heritability in broad sense, Genetic advance (GA) was determined as described by Johnson et al. (1955) as follows:

$$
\mathrm{GA}=\mathrm{K} \delta_{\mathrm{p}} \mathrm{h}^{2} \text {, }
$$

Where: $\mathrm{K}=$ The selection differential ( $\mathrm{K}=2.06$ at $5 \%$ selection intensity); $\sigma_{\mathrm{p}}$ $=$ the phenotypic standard deviation of the character; $\mathrm{h}^{2}=$ broad sense heritability. The genetic advance as percentage of the mean (GAM) was calculated as follows:

$$
\mathrm{GAM}=\frac{\mathrm{GA}}{\mathrm{x}} \mathrm{X} 100,
$$

Where: GAM = genetic advance as percentage of the mean, GA= genetic advance, and $\mathrm{x}=$ grand mean of a character. Traits were categorized depending on the degree of heritability percentage as low $(<40 \%)$, medium $(40-59 \%)$, moderately high $(60-79 \%)$ and very high $(\geq 80 \%)$ as reported by Singh 2001.

\section{Cluster analysis}

Distance based hierarchical cluster analysis was performed to group genetically similar genotypes together through a repetitive process that results in cluster formation by using Darwin software version 6.0.21 (Perrier and Jacquemoud-Collet,2006) using dissimilarity index based on Euclidean distance of the standardized variables. 


\section{RESULTS AND DISCUSSION}

\section{Industrial zerformance of the genotypes}

The juice purity of the genotypes ranged between $46.04 \%$ and $100 \%$ (Table 1). Three Sweet sorghum cultivars were characterized for Juice brix, Total soluble sugar, reducing sugar\%, Sucrose $\%$ and Purity $\%$ (Rao and Kumar, 2013).), SSV74(17.78, 15.36, 1.16, 13.49, 75.64), SPSSV30 (20.73, $15.81,0.45,14.59,72.02)$ and CSH22SS (16.48 13.501 .2911 .68 70.70). These commercial varieties were found to be outperformed by the landrace collections tested in this study for all the five parameters showing that there is a good possibility to breed sweet sorghum cultivars with better juice quality traits. The sucrose percent (pol) of the genotypes was found to range between 7.2 and 17.76 percent. This is higher than the values reported to commercial sweet sorghum varieties (Rao et al., 2013) who reported a range of sucrose percent between 8.3 and 11.2 for three varieties (SSV84, SSV74, and CSV19SS) and one hybrid (CSH22SS). Another study in Turkey also reported a sucrose percent of values ranging between 8.02 and 10.63 in a study that is conducted on nine genotypes and four commercial varieties (Erdurmus et al., 2018). The total soluble solids of the test genotypes had displayed a maximum value of 24.5 and a minimum of 10 and these values are significantly higher when compared to varieties commercial varieties like CV147, CV198 and BRS508 (Silva et al., 2016).

Analysis of juice quality on the sweet sorghum variety Mn 4080 indicated mean values of sucrose percent and total soluble solids of 11.2 and 16.72 respectively, which is significantly lower than the value reported in the current work (Soha et al., 2019). This indicates the fact that there is a huge variation in the juice quality traits of the studied genotypes that can be used for future improvement of sweet sorghum juice qualities.

This result confirmed the fact that ample amount of variability is displayed for these characters that can be exploited in the future improvement of sweet sorghum. The same finding is also reported by different authors (Lekgari and Dweikat, 2014; Alina, 2019; Yücel et al., 2020). The variation due to years and the interaction between year and genotypes were found to be non-significant for all the measured characters. This may not reflect the absence of environmental and genotype $\mathrm{X}$ environment interaction on the recorded traits because our experiment was performed at a single location, same season (date of sowing) and under fully irrigated condition limiting the variation of the two experiments. Otherwise, significant genotype by 


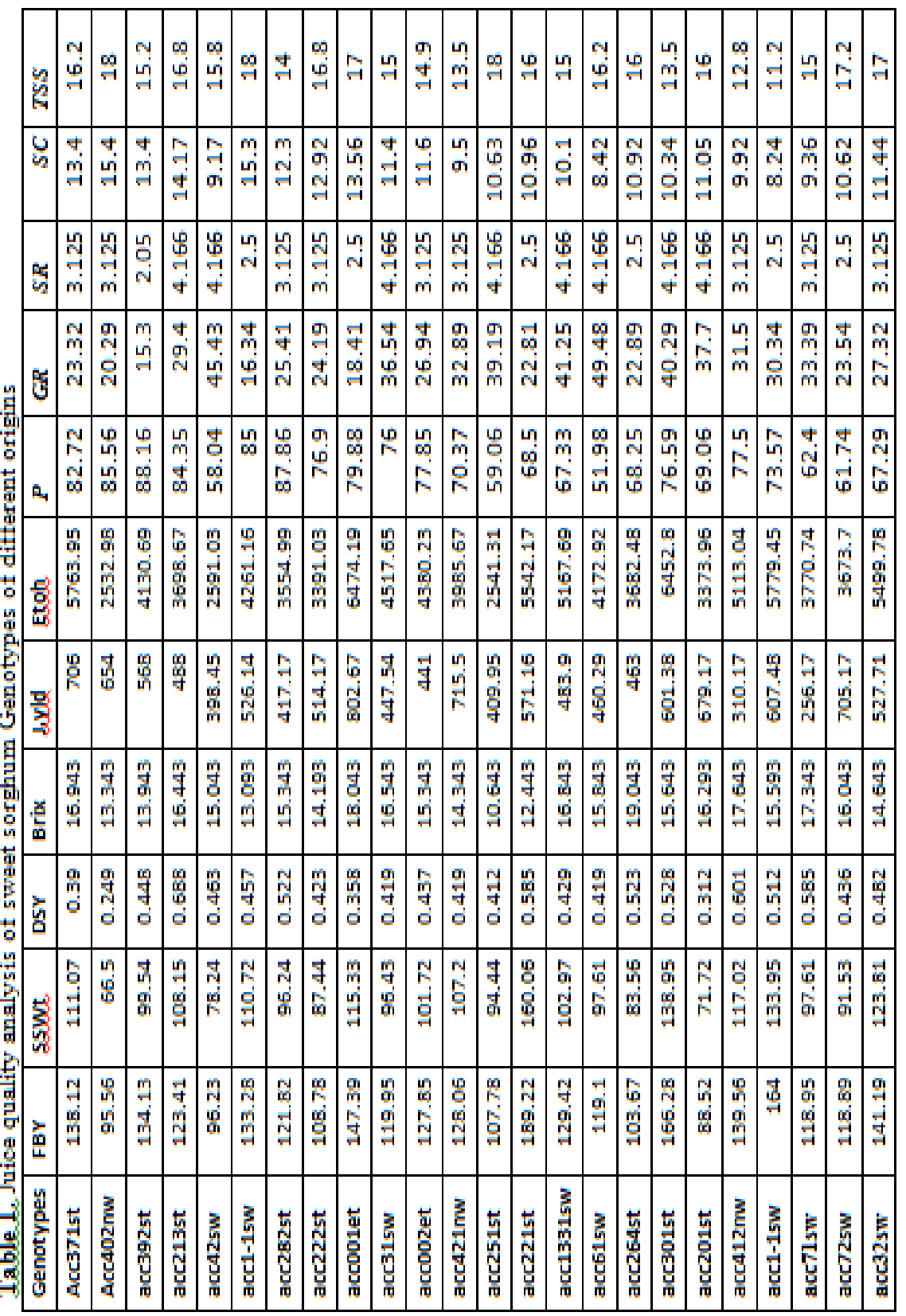




\begin{tabular}{|c|c|c|c|c|c|c|c|c|c|c|c|c|c|c|c|c|c|c|c|c|c|c|c|c|}
\hline & $\mid$ & 胥 & 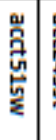 & 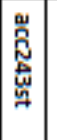 & 崫 & 䓌 & 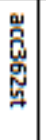 & 峛 & 嵹 & 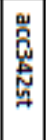 & 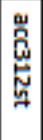 & 岂 & 唇 & 罭 & 䍘 & 魫 & 罗, & 䍐 & 罚 & 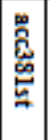 & 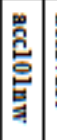 & & 罖 & $\begin{array}{l}\text { 罯 } \\
\text { 总 }\end{array}$ \\
\hline & $\begin{array}{l}\vec{y} \\
\vdots \\
\end{array}$ & 岁 & $\begin{array}{l}10 \\
0 \\
3\end{array}$ & \begin{tabular}{|c|} 
\\
0 \\
$w$ \\
$\vdots$ \\
\end{tabular} & $\begin{array}{l}\text { 思 } \\
\vdots \\
\vdots \\
\end{array}$ & 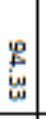 & $\begin{array}{l}\text { 品 } \\
\text { 出 } \\
\end{array}$ & 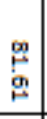 & \begin{tabular}{|l} 
\\
0 \\
$i n$ \\
$w$ \\
\end{tabular} & \begin{tabular}{|l}
5 \\
0 \\
3 \\
\end{tabular} & 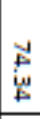 & \begin{tabular}{|l} 
\\
$\overline{0}$ \\
5 \\
5
\end{tabular} & $\begin{array}{l}5 \\
\mathbf{u} \\
\mathbf{E}\end{array}$ & $\begin{array}{l}\text { 总 } \\
\text { 吕 } \\
\end{array}$ & 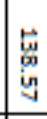 & 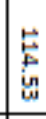 & $\begin{array}{l}\text { 足 } \\
\text { N } \\
\end{array}$ & 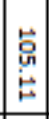 & \begin{tabular}{|l}
5 \\
5 \\
0 \\
0 \\
0
\end{tabular} & \begin{tabular}{|l} 
\\
0 \\
0 \\
\end{tabular} & 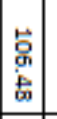 & 点 & $\begin{array}{c}\overrightarrow{5} \\
\dot{*} \\
\end{array}$ & $\begin{array}{l}\text { 怘 } \\
\vdots \\
\vdots \\
\end{array}$ \\
\hline & 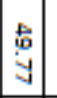 & $\begin{array}{ll}\mathrm{N} \\
\mathrm{N}\end{array}$ & $\mid \begin{array}{l}5 \\
0 \\
0 \\
0\end{array}$ & & & 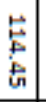 & & & 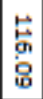 & \begin{tabular}{|l}
$\vec{N}$ \\
N \\
年
\end{tabular} & $\begin{array}{l}\text { 思 } \\
0 \\
\dot{8}\end{array}$ & \begin{tabular}{|l}
5 \\
a \\
0
\end{tabular} & $\begin{array}{l}5 \\
-5 \\
9\end{array}$ & 窎 & & 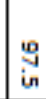 & 总 & 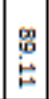 & 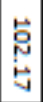 & $\left|\begin{array}{l}\mathbf{n} \\
\text { ing } \\
\text { ig }\end{array}\right|$ & $\mid \begin{array}{l}0 \\
y \\
9 \\
9\end{array}$ & $\begin{array}{l}\text { 崽 } \\
\text { 离 }\end{array}$ & 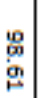 & 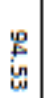 \\
\hline & 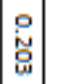 & 总 & \begin{tabular}{|c|} 
\\
9 \\
0 \\
\end{tabular} & & 恙 & 号 & 吾 & 号 & 总 & 识 & 品 & 总 & 点 & 尊 & 总 & 总 & 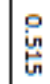 & $\begin{array}{l}\mathrm{O} \\
\mathrm{H} \\
\mathrm{H} \\
\mathrm{\omega}\end{array}$ & $\begin{array}{l}0 \\
y \\
y \\
t\end{array}$ & \begin{tabular}{|l} 
足 \\
葛
\end{tabular} & $\begin{array}{l}0 \\
\text { 意 } \\
\end{array}$ & 是 & 忠 & $\begin{array}{l}0 \\
\text { in } \\
\text { पit }\end{array}$ \\
\hline & 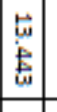 & 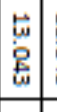 & ${ }^{\omega}$ & & 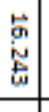 & $\begin{array}{c}\text { 欱 } \\
\text { 思 } \\
\end{array}$ & 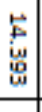 & 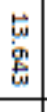 & 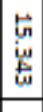 & \begin{tabular}{|l} 
\\
点 \\
总 \\
\end{tabular} & 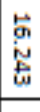 & 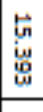 & 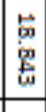 & 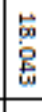 & \begin{tabular}{|l} 
\\
点 \\
总 \\
\end{tabular} & \begin{tabular}{|l} 
\\
点 \\
量 \\
\end{tabular} & 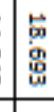 & 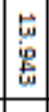 & $\begin{array}{l} \\
\text { 点 } \\
\text { 总 } \\
\end{array}$ & 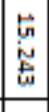 & 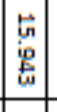 & 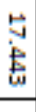 & 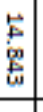 & 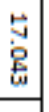 \\
\hline & $\begin{array}{l}\text { 高 } \\
\text { iog } \\
\text { o }\end{array}$ & 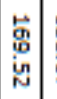 & $\begin{array}{l}0 \\
0 \\
0 \\
g \\
g\end{array}$ & $\mid \begin{array}{l}5 \\
\vdots \\
9 \\
9\end{array}$ & $\begin{array}{l}\mathrm{N} \\
\mathrm{N} \\
\mathrm{N}\end{array}$ & 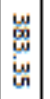 & $\begin{array}{l}\text { ung } \\
9 \\
g\end{array}$ & & 㕝 & $\begin{array}{l}\text { 点 } \\
\text { g. }\end{array}$ & 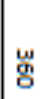 & 嵒 & 总 & जे & की & 总 & $\underset{\mathbb{N}}{\mathrm{E}}$ & 䎏 & 誉 & $\begin{array}{l}\text { 员 } \\
\text { 总 } \\
\text { in }\end{array}$ & 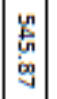 & $y$ & 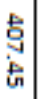 & 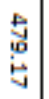 \\
\hline & 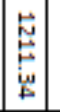 & $\begin{array}{c}0 \\
0 \\
0 \\
0 \\
0\end{array}$ & $\mid \begin{array}{c}0 \\
0 \\
0 \\
0 \\
ث \\
ث\end{array}$ & 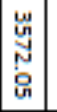 & $\mid$ & 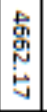 & 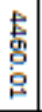 & 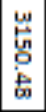 & 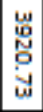 & $\begin{array}{l}\text { 总 } \\
\text { 总 } \\
\text { 品 }\end{array}$ & 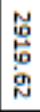 & 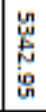 & 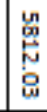 & 芯 & $\begin{array}{l}\text { 总 } \\
\text { in } \\
\text { in }\end{array}$ & 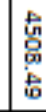 & $\begin{array}{l}n \\
0 \\
0 \\
0 \\
0 \\
w\end{array}$ & 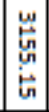 & $\begin{array}{l}\text { 䓌 } \\
0 \\
0 \\
\text { o. } \\
\end{array}$ & 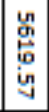 & 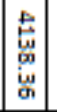 & 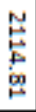 & 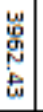 & \begin{tabular}{l} 
岁 \\
\multirow{3}{*}{}
\end{tabular} \\
\hline & $\begin{array}{c}\text { 怘 } \\
\text { 心 }\end{array}$ & 18 & $\begin{array}{l}\delta \\
\delta \\
g \\
g\end{array}$ & & & \begin{tabular}{|l}
$:$ \\
0 \\
0 \\
0 \\
\end{tabular} & 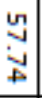 & & $\begin{array}{l}0 \\
0 \\
\dot{\omega} \\
.\end{array}$ & 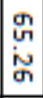 & $\begin{array}{l}\infty \\
+ \\
i v \\
\end{array}$ & & & & & 学 & & & 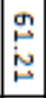 & & 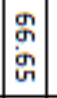 & 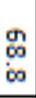 & 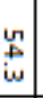 & \\
\hline & $\left|\begin{array}{l}0 \\
+ \\
+ \\
\pm\end{array}\right|$ & $\mid \begin{array}{l}0 \\
u \\
i n \\
y\end{array}$ & $\left|\begin{array}{l}w \\
\vec{u} \\
\vdots \\
\sim\end{array}\right|$ & \begin{tabular}{|c|c} 
\\
$w$ \\
$i$ \\
$\infty$ \\
$\infty$
\end{tabular} & & $\underset{\text { in }}{\mathbf{N}}$ & $\begin{array}{l}\mathbf{N} \\
\mathbf{N} \\
\mathbf{N}\end{array}$ & 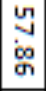 & $\mid \begin{array}{c}w \\
\infty \\
o \\
o \\
\sigma\end{array}$ & $\mid \begin{array}{c}n \\
n \\
i \\
N\end{array}$ & \begin{tabular}{|l}
5 \\
o
\end{tabular} & 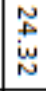 & w & & & $\frac{⿱}{\infty}$ & & & $\begin{array}{l}\text { in } \\
0 \\
\text { in } \\
\end{array}$ & & $\left|\begin{array}{c}w \\
+ \\
w \\
+ \\
+\end{array}\right|$ & 莕 & $\begin{array}{l}0 \\
0 \\
\vdots \\
\vdots \\
\oplus\end{array}$ & \\
\hline & \begin{tabular}{l}
$N$ \\
\hdashline \\
$\infty$
\end{tabular} & $\begin{array}{l}w \\
\dot{\omega} \\
\vec{w} \\
v\end{array}$ & $\mid \begin{array}{l}w \\
\dot{b} \\
心 \\
\sim\end{array}$ & 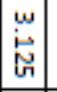 & & \begin{tabular}{|l}
$\mathbf{w}$ \\
$\dot{\omega}$ \\
$\dot{w}$ \\
\end{tabular} & \begin{tabular}{|l}
$w$ \\
$\dot{\omega}$ \\
$\vec{w}$ \\
\end{tabular} & \begin{tabular}{|l}
$\vec{i}$ \\
$\dot{s}$ \\
\end{tabular} & 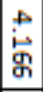 & \begin{tabular}{|l}
$w$ \\
$\dot{w}$ \\
$\vec{w}$ \\
\end{tabular} & \begin{tabular}{|l}
$w$ \\
$\dot{w}$ \\
$\vec{w}$ \\
$心$
\end{tabular} & in & $\mid \overrightarrow{\dot{*}}$ & $\begin{array}{l}w \\
\dot{w} \\
\omega \\
N\end{array}$ & 薃 & 察 & & 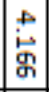 & $\begin{array}{l}0 \\
\dot{1} \\
\omega\end{array}$ & $\stackrel{\vec{i}}{\dot{\mathbf{g}}}$ & 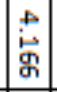 & \% & $\begin{array}{r}3 \\
i \\
-1\end{array}$ & \\
\hline & $\mid \begin{array}{l}\infty \\
\text { in }\end{array}$ & $\begin{array}{l}\stackrel{1}{N} \\
\text { N } \\
\text {. }\end{array}$ & |히 & $\begin{array}{l}1 \\
\text { N } \\
\text {. }\end{array}$ & & $\begin{array}{c}0 \\
\vdots \\
\end{array}$ & $\checkmark$ & in & 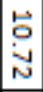 & 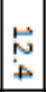 & $\begin{array}{l}\stackrel{5}{2} \\
\text { ơ }\end{array}$ & \begin{tabular}{|l}
$\overrightarrow{0}$ \\
品 \\
D
\end{tabular} & $\begin{array}{l}\stackrel{\vec{N}}{N} \\
\dot{w} \\
+\end{array}$ & in & $\begin{array}{l}0 \\
\vdots \\
0\end{array}$ & $\mid \begin{array}{c}\infty \\
\text { a } \\
\infty\end{array}$ & & 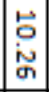 & $\begin{array}{l}\stackrel{.}{N} \\
\dot{\omega} \\
\mathrm{N}\end{array}$ & 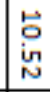 & 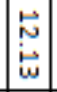 & 总 & $\begin{array}{c}\infty \\
i \\
i \infty \\
\infty\end{array}$ & \\
\hline & 它 & $\left|\begin{array}{l}\stackrel{1}{N} \\
N \\
N \\
N\end{array}\right|$ & & & & & & & & & & in & & סू & ת & in & & & & के & $\left|\begin{array}{l}\infty \\
\dot{w} \\
i \sim\end{array}\right|$ & & जी & \\
\hline
\end{tabular}




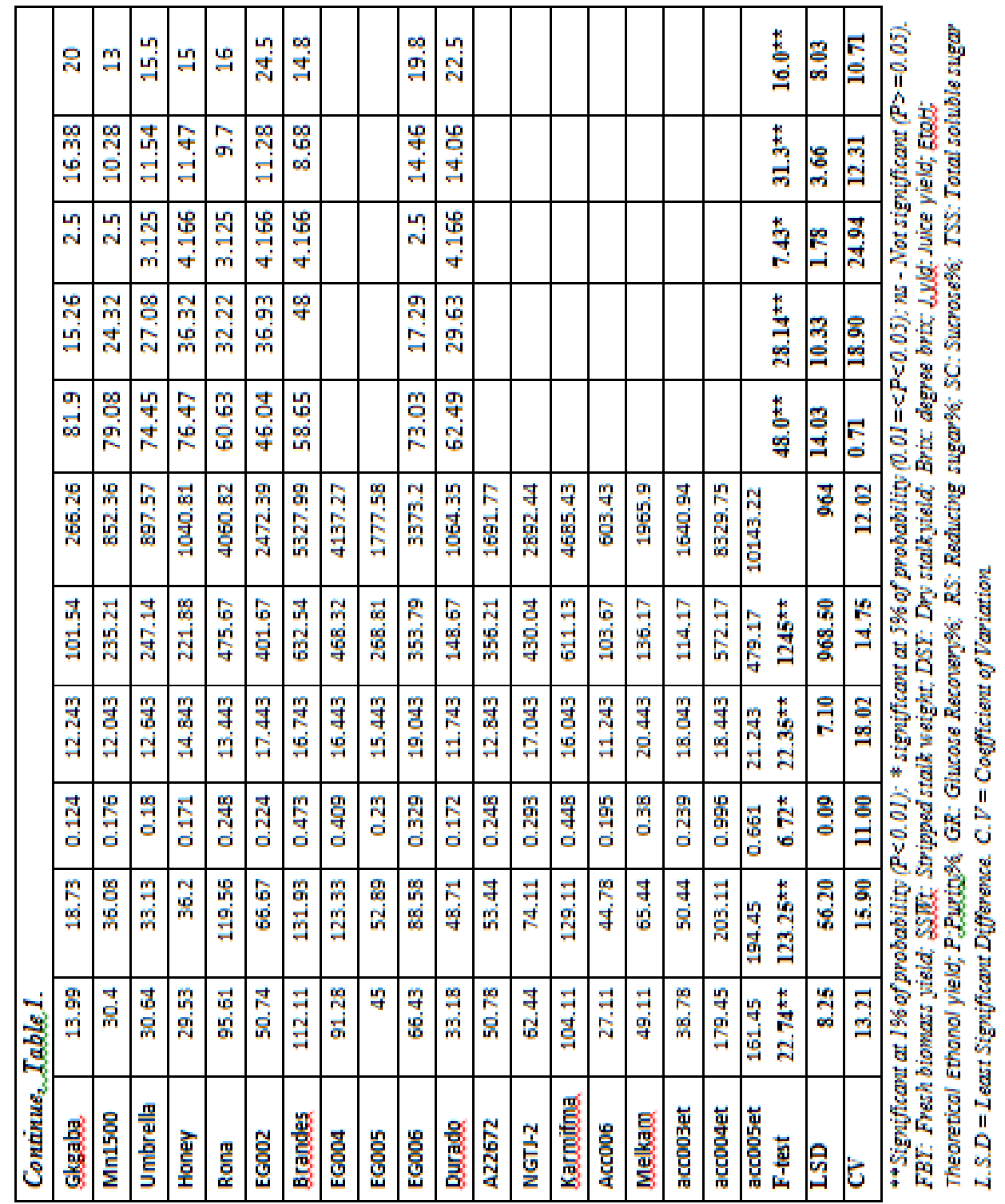


environment interactions were reported in many reports with respect to the above traits except for fresh biomass yield and fresh stalk yield (Makanda, 2009; Zou et al., 2011; Elangovan et al., 2014).

\section{Analysis of variance}

The genotypes showed significant level of variation at $\mathrm{P} \leq 0.01$ for all the eleven industrial traits (Table 2) evaluated regarding the five juice quality parameters measured (Purity, Sucrose recovery, Sugar recovery, sucrose content and total soluble solids).

Table 2. Trait mean Squares in a combined analysis of variance over two years of eleven industrial traits in 68 sweet sorghum genotypes.

\begin{tabular}{|l|c|c|c|c|}
\hline \multicolumn{1}{|c|}{ Trait } & Genotype & Replication & Year & Residual \\
\hline Purity\% & $524.5^{* *}$ & 34.85 & 32.30 & 14.13 \\
\hline Glucose Recovery\%; & $53.54 * *$ & 9.58 & 7.35 & 6.62 \\
\hline Total soluble sugar & $465.19^{* *}$ & 151.61 & 82.79 & 36.68 \\
\hline Fresh biomass yield (Ton/ha) & $9775.913^{* *}$ & 435.45 & 278.88 & 136.08 \\
\hline Reducing sugar\% & $4.17^{* *}$ & 0.91 & 0.21 & 0.14 \\
\hline Stripped Stalk weight (Ton/ha) & $7262.482^{* *}$ & 253.62 & 158.56 & 73.49 \\
\hline Dry Stalk yield (Kg/plant) & $5214^{* *}$ & 146.51 & 101.24 & 65.73 \\
\hline Brix (\%) & $6.86^{*}$ & 0.073 & 0.049 & 0.0014 \\
\hline Juice yield (gm/plant) & $203061.7 * *$ & 9728.52 & 1482.04 & 1888.95 \\
\hline Sucrose\% & $40.81^{*}$ & 9.86 & 6.87 & 3.70 \\
\hline Ethanol yield (liter/ha) & $3093.42^{* *}$ & 1847.479 & 577.44 & 117.29 \\
\hline
\end{tabular}

* Significant at $\mathrm{P} \leq 0.05 ; * *$ Significant at $\mathrm{P} \leq 0.01$

\section{Variance components and genetic parameters}

Estimation of variance components and their corresponding heritable portion is very important for future improvement efforts (Zou et al., 2011; Elangovan et al., 2014). Since the phenotypic and genotypic variance estimates depends on the unit by which the character is measured, they cannot be used to compare variations among the different characters. Hence, the phenotypic and genotypic coefficients of variation (PCV and GCV) were used to compare the different characters (Table 3). Most of the measured traits showed lower coefficient of variation $(\mathrm{CV})$ except fresh biomass yield 


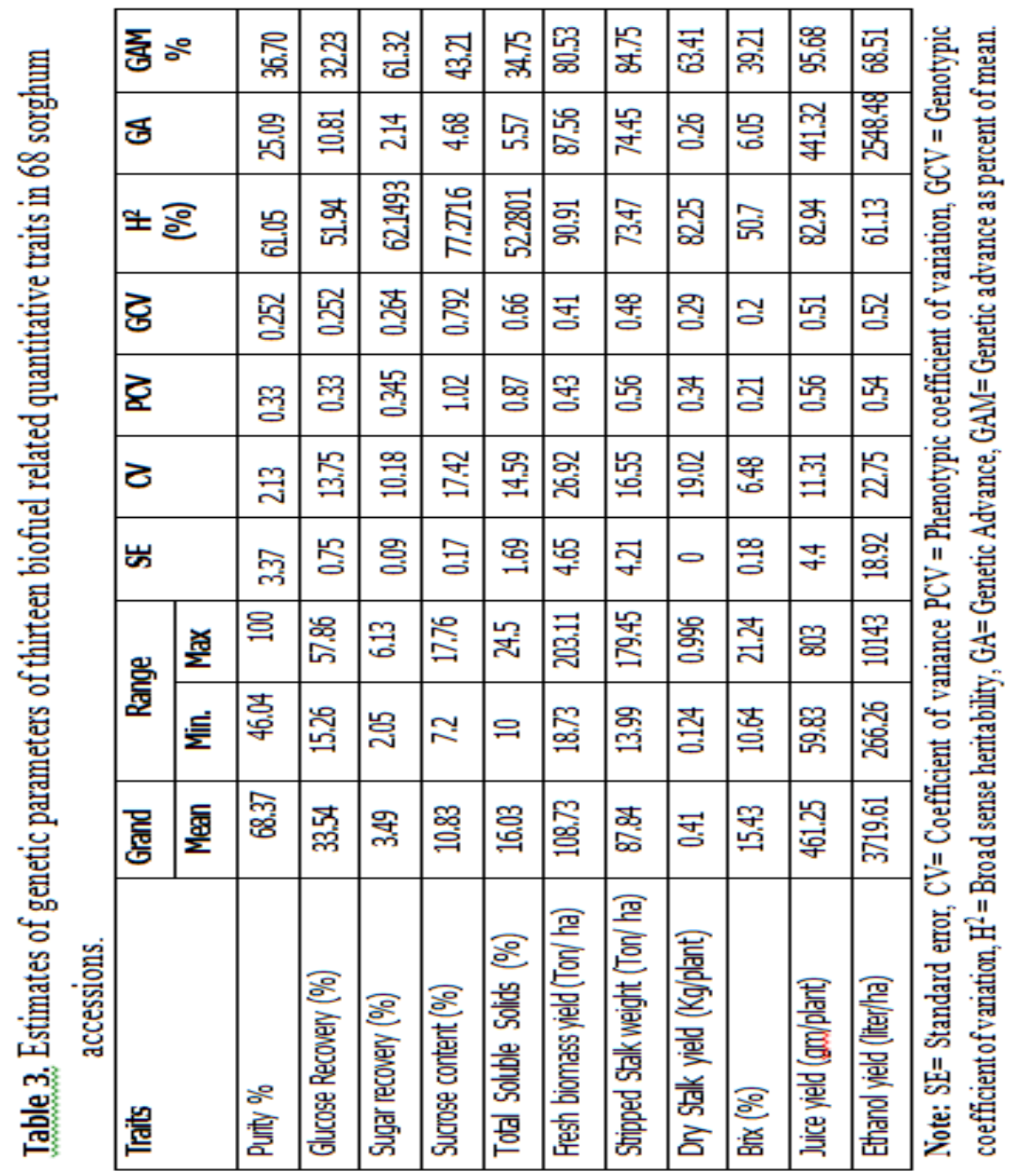


(26.92), stripped stalk weight (16.55) and estimated ethanol yield (22.75) depicting the fact that the environment has got some bearing in the expression of these characters (Sinha and Kumaravadivel, 2016).

For most of the traits there is a narrow difference between PCV and GCV indicating lower environmental influence in the expression of the traits (Godbharle et al., 2010). Higher values of PCV and GCV in some characters including ethanol yield signifies possibility of effective selection for superior genotypes while lower values of PCV and GCV in traits like purity \% and brix indicate the limited possibility of improvement via selection (Elangovan et al., 2014; Reddy, 2009). All the measured characters exhibited moderate to high broad sense heritability ranging from 50.7 (brix) to 90.1 (FBY). The juice yield, fresh biomass yield, plant height, days to flowering number of leaves, brix and stem diameter showed higher ( $>80$ ) value of heritability. The broad sense heritability for these characters is reported to be lower than the value recorded in the present study (Murray et al.2008; Shiringani et al. 2010; Disassa et al., 2016).Lower heritability estimate was recorded for brix and glucose recovery as compared to other characters and this result is in agreement with Dissasa et al., 2016.

\section{Cluster analysis}

The sixty-eight sweet sorghum genotypes were categorized based on the eleven quantitative traits using cluster analysis. The test genotypes were found to be clustered into five distinct clusters (Figure 1). The first cluster is composed of twenty-six mostly comprising landrace collections from south Tigray.

The second cluster contain twelve accessions mostly from north and south wollo. Two accessions are grouped together forming the third cluster. Sixteen accessions collected from north wollo and south wollo regions combined with Ethiopian improved accessions were grouped together forming the fourth cluster. The final cluster was found to contain entirely Egyptian cultivars forming the fifth cluster. This showed the presence of population differentiation between Egyptian and Ethiopian cultivars. Three accessions that are collected from Gojam area were remained as outliers at the coefficient of similarity the other clusters were classified this may be because these accessions were collected from distant places in the area. 


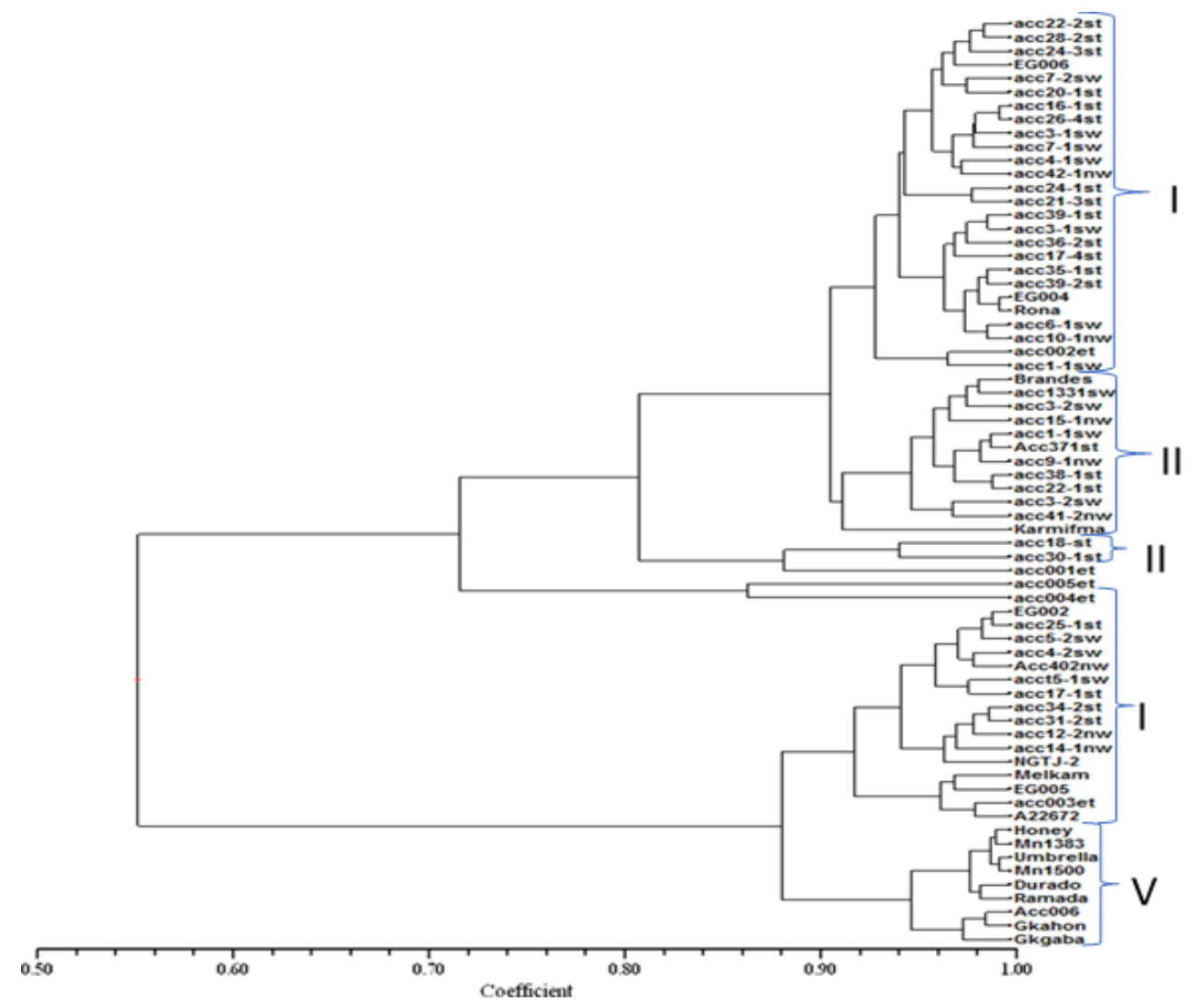

Figure 1: Dendrogram of 68 sweet sorghum accessions revealed by cluster analysis based on genetic similarity estimatesgenerated by Nei and Li coefficient based on 19 agro-morphological characters.

Cluster analysis based on phenotypic traits could show some level of inconsistency to their genealogy and historic background due to the presence of significant genotype by environment interaction (Da-silva et al., 2017). This is also reflected in the current study where some accessions that do not share similarity and descent were found to end in the same cluster. On the hand most accessions in the preset studies were comprised of accessions sharing the same geographic origin with only minimal mixtures.

Conclusively, the tested sweet sorghum genotypes displayed a broad range of variability in terms of all the measured industrial crops. The juice quality parameters in the test genotypes were found to be significantly higher 
as compared to different commercial improved cultivars. This indicates the presence of promising possibility for the future improvement of the crop. The test genotypes were found to be clustered into five distinct clusters.

\section{REFERENCES}

Alina, M., Hussein, S., Laing, M., and Shargie, N. (2019). Genetic variability, heritability and genetic gain for quantitative traits in South African sorghum genotypes. AJCS, 13(01):1-10, ISSN:1835-2707 doi: 10.21475/ajcs.19.13.01. p718

Almodares, A. and Hadi, M. R. (2009). "Production of bioethanol from sweet sorghum: A review. African Jour.of Agricultural Research 4 (9): 772-780.

Almodares, A., \& Sepahi, A. (1996). Comparison among sweet sorghumcultivars, lines and hybrids for sugar production. Annals of Plant Physiology, 10: 50-55.

Al-Naggar, A.M.M.; El-Kadi, D.A. and Abo-Zaid, Z.S.A. (2007). Inheritance of nitrogen use efficiency traits in grain sorghum under low-and high-N. Egypt. J. Plant Breed. 11(3):181- 206.

A.O.A.C. (2005). Association of Official Agricultural Chemist. Official Methods of Analysis. published by the A.O.A.C., Washington, U.S.A.

Burks, P.S., Felderhoff, T.J., Viator, H.P., Rooney, W.L. (2013). The Influence of Hybrid Maturity and Planting Date on Sweet Sorghum Productivity during a Harvest Season. Agron J. 105: 263 267 . https://doi.org/10. 2134/agronj2012.0317.

Burks, P.S., Kaiser, C.M., Hawkins, E.M., Brown, P.J. (2015). Genome wide associationfor sugar yield in sweet sorghum. Crop Sci.55: 2138-2148.

Elangovan, M., Kiran, B. .P, Seetharama, N., Patil, J. V. (2014). Genetic Diversity and Heritability Characters Associated in Sweet Sorghum [Sorghum bicolor (L.) Moench]. Sugar Tech. 16: 200-210. https://doi.org/10.1007/s12355-013-0262-5.

Erdurmus, C., Yucel, C., Cinar, O., Yegin, A. B., Oten, M. (2018). Bioethanol and Sugar Yields of Sweet Sorghum. The Int. J. of Eng. and Sci. (IJES)7: 11. Pp. 21-26. ISSN (e): 2319-1813 ISSN (p): 23-19- 1805 DOI:10.9790/1813-0711022126.

FAO (2019). Food and Agriculture Organization. Food And Agriculture Data. Available at: http://www.fao.org/faostat/en/\#data/QC (Accessed 14 January 2019). 
Khaled, A.G.A.; El-Sherbeny G.A.R. and Hadeer S. A. Abdelaziz (2019). SRAP and ISSR Molecular Markers-trait Associations in Sorghum Genotypes. Assiut J. Agric. Sci., 50 (2) :159-175).

Lekgari, A. and Dweikat, I. (2014). Assessment of genetic variability of 142 sweet sorghum germplasm of diverse origin with molecular and morphological markers. Open J Ecol. 4: 371-393.

Lueschen, W.E., Putnam, D.H., Kanne, B.K., Hoverstad, T.R. (1991). Agronomic practices for production of ethanol from sweet sorghum. $J$. Prod. Agric.4: 619-625.

Makanda, I., Tongoona, P., \& Derera, J. (2009). Combining ability and heterosis of sorghum germplasm for stem sugar traits under off-season conditions in tropical lowland environments. Field Crops Research, 114: 272-279. https ://doi.org/10.1016/j.fcr.2009.08.009

Mocoeur, A., Zhang, Y.M., Liu, Z.Q., Shen, X., Zhang, L.M., Rasmussen, S.K., Jing, H.C. (2015). Stability and genetic control of morphological, biomass and biofuel traits under temperate maritime and continental conditions in sweet sorghum (Sorghum bicolour). Theor. Appl. Genet. 128:1685-1701.

Packer, D.J., and Rooney W.L. (2014). High-parent heterosis for biomass yield in photoperiod-sensitive sorghum hybrids. Field Crops Research167: 153-158.

Rao P. S., Kumar, C. G. (2013). Characterization of Improved Sweet Sorghum Cultivars. ISSN 2211-808X ISSN 2211-8098 (electronic) ISBN 978-81322-0782-5 ISBN 978-81-322-0783-2 (eBook) DOI 10.1007/978-81-3220783-2. Springer New Delhi Heidelberg New York Dordrecht London.

Regassa, T.H., Wortmann, C.S. (2014). Sweet sorghum as a bioenergy crop: literature review. Biomass Bioenergy. 64: 348- 355 .

Rooney, W.L., Blumenthal, J., Bean, B., Mullet, J.E. (2007). Designing sorghum as a dedicated bioenergy feedstock. Biofuel Bioprod. Biorefin. 1: 147-157. https://doi. org/10.1002/bbb.15.

SAS (2011). Windows Version 1.4. SAS Institute Inc., Cary, NC, USA.

Silva, A. F., Ferreira, O. E., Costa, G. H. G., Montijo, N. A., Mutton, M. A., Mutton, M. J. R. (2016). Technological quality of sweet sorghum processed without panicles for ethanol production. AJCS, 10(11): 15781582 ISSN:1835-2707 doi: 10.21475/ajcs.2016.10.11. p7697. 
Teshome, A., Baum, B.R, Fahrig, L., Torrance, J.K., Arnason, T.J. \& Lambert, J.D. (1997). Sorghum [Sorghum bicolor (L.) Moench] landrace variation and classification in North Shewa and SouthWelo, Ethiopia. Euphytica, 97: 255-263, 1997.255.

Yücel, Derya, Hızl, Hatice, Yucel, C. and Dweikat I. (2020). Genetic Variability, Heritability, and Genetic Advance for Ethanol Yield and Yield Components in Sweet Sorghum (Sorghum Bicolor Var. Saccharatum (L.). Int. J. In. App. in Agri. Res. 4(1): 21-32.

Wang, L., Jiao, S., Jiang, Y., Yan, H., Su, D., Sun, G., Yan, X., Sun, L. (2013). Genetic diversity in parent lines of sweet sorghum based on agronomical traits and SSR markers. Field Crop Res. 149: 11-19. doi: 10.1016/j.fcr.2013.04.013.

Wortmann, C.S., Liska, A.A., Ferguson, R.B., Lyon, D.J., Klein, R.N., Dweikat, I.M. (2010). Dryland performance of sweet sorghum and grain crops for biofuel in Nebraska. Agron. Journal, 102: 319-326. https://doi.org/10.2134/agronj2009.0271.

Wu, X., Staggenborg, S., Propheter, J. L., Rooney, W.L Yu, J. and Wang, D. (2010). "Features of sweet sorghum juice and their performance in ethanol fermentation." Industrial Crops and Products 31 (1): 164-170.

Zou, G., Yan, S., Zhai, G., Zhang, Z., Zou, J., and Tao, Y. (2011). Genetic variability and correlation of stalk yield-related traits and sugar concentration of stalk juice in a sweet sorghum (Sorghum bicolor L. Moench) population. Australian Journal of Crop Science5:1232-1238. 
أداء مصادر الأصول الوراثية للأرة الرفيعة الحلوة (Sorghum bicolor L.) لصفاتها الصناعية في ظل الظروف المصة المصرية

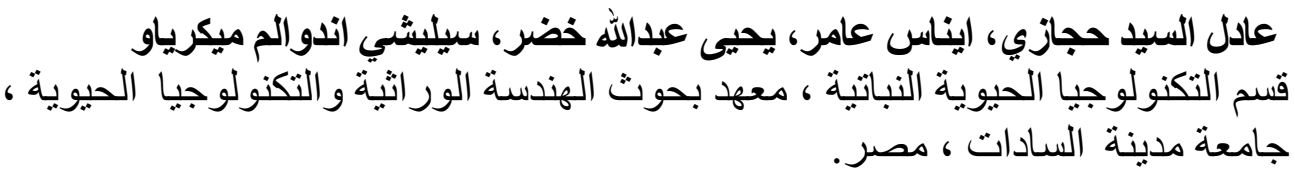

الذرة الرفيعة الحلوة هي أحد أنواع المحاصبل الناشئة متعددة الاستخدامات التي تقدم

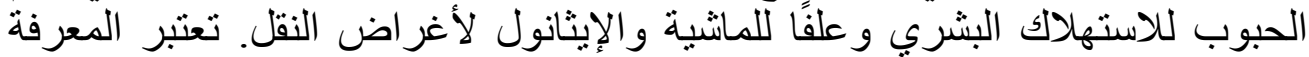

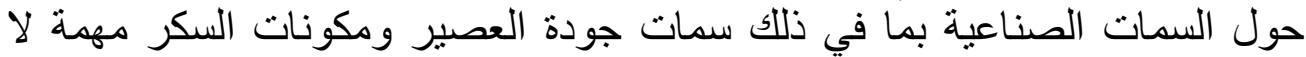

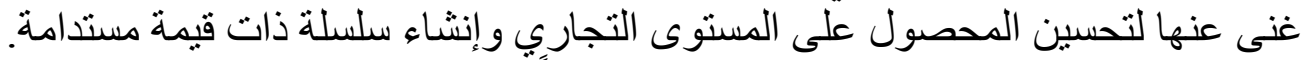

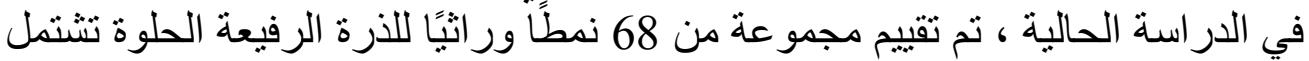

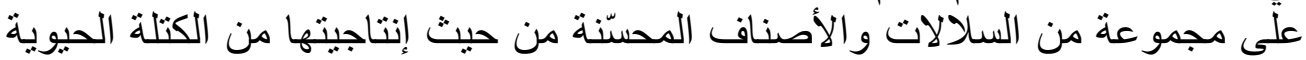

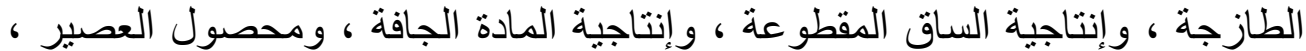

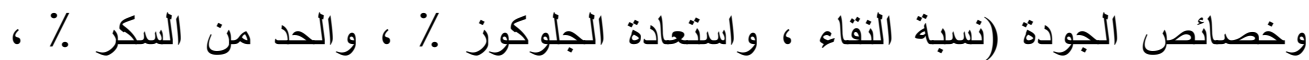
السكروز \% ، و السكر الكلي القابل للذوبانة). أظهرث النتائج ان التراكيب الجينية مستوى معنوي من التباين عند

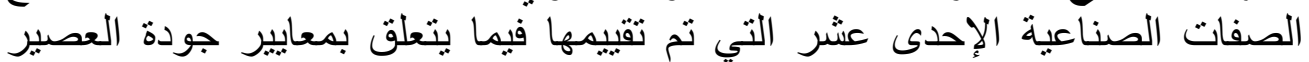

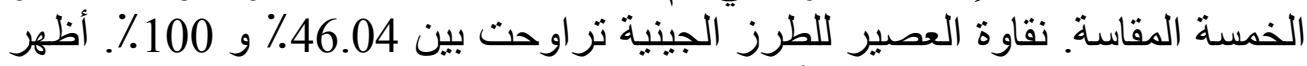

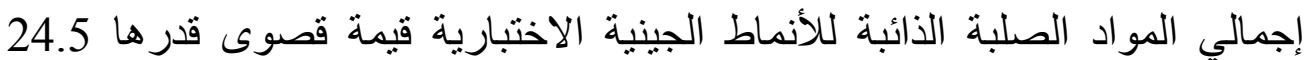

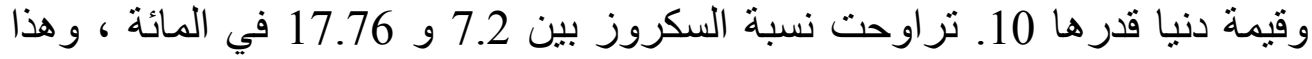

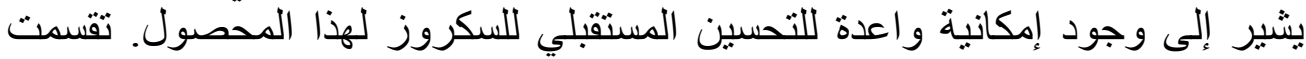

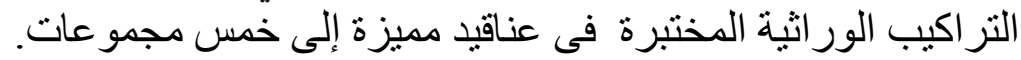

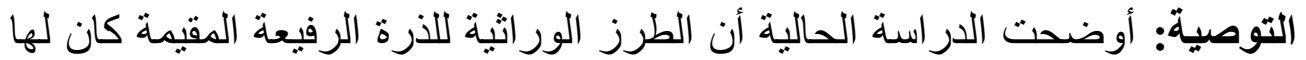
أداء متفوق من حيث إنتاجية العصير وصفات الجودة. وبالتالي ، يمكن استخلالها في التحسين المستقبلي للمحصول كمن حصصول صناعي. 